https://doi.org/10.31470/2706-7904-2021-16-213-217

\title{
PSYCHOLINGUISTIC FEATURES OF EXPLICATION OF LINGUOCULTURAL MODEL “CLOTHING” IN ENGLISH AND UKRAINIAN
}

\section{Психолінгвістичні особливості експлікації лінгвокультурної моделі «одяг» англійською та украӥнською мовами}

\author{
Nataliia Mykhalchuk \\ Dr. Sc. in Psychology, Professor \\ Rivne State University of the Humanities (Ukraine) \\ Natasha1273@ukr.net \\ https://orcid.org/0000-0003-0492-9450 \\ Pavlo Levchuk \\ Ph.D. in Philology, Adjunct Professor \\ Institute of Slavic Studies (Poland) \\ p.levchuk@ispan.waw.pl \\ https://orcid.org/0000-0001-7865-6833 \\ Nataliia Khupavtseva \\ Dr. Sc. in Psychology, Professor \\ Rivne State University of the Humanities (Ukraine) \\ natalahupavceva@gmail.com \\ https://orcid.org/0000-0002-8883-7686
}

\begin{abstract}
To understand the linguocultural units of the thematic group "clothing" in the English language, it is important to master the principles of nomination of lexical units, such as the principle of nomination "a form", the principle of nomination "a purpose of use of a thing (a purpose)" or "clothing as a material having been used", the principle of nomination "social, national and professional affiliation". For the understanding of linguocultural units of the thematic group "clothing" in the Ukrainian language the laws of organization of usual and actual communicative meanings, their interaction, movement, etc. are quite important, then for understanding linguocultural units of the thematic group "clothing" in the English language is sufficient superficial perception of lexical units that denote the nominations of clothing, understanding the features of their motivation, in particular, verbs, nouns and adjectives, as well as mastering the form of presentation of this or that lexical unit.
\end{abstract}

Key words: linguocultural models "clothing", the principles of nomination of lexical units, understanding of inferences, implications. 


\section{Introduction}

Bcmyn

In psycholinguistics, researchers define "nomination" as a combination of generalizing content and speech activity, as well as the person's thinking (Drigas, \& Karyotaki, 2017). Thus, in the process of its creation the word goes from a mentally significant paradigm to communication, and, that is why, the study of the lexical level of any language should cover all stages of the formation of speech activity in a way from the creation of speech clichés to their functioning (Alahmadi \& Foltz, 2020). Since the beginning of psycholinguistics as a science, researchers have not abandoned any attempts to study the process of actualization of mental images and facts of the surrounding reality, their transition to the facts of the language (Mykhalchuk \& Bihunova, 2019).

So, the purpose of the article is: to show psycholinguistic peculiarities of understanding by Ukrainian students the principles of nomination of linguocultural models "clothing" in the English and Ukrainian languages.

\section{Methods and techniques of the research Методи і процедури дослідження}

The methods of the research are: theoretical ones - categorical and structurallyfunctional analysis of the texts, the methods of systematization, modeling, generalization; empirical methods - the analysis of lexical units, the experiment. For the purpose of studying the motivation of linguocultural units we used "The methods of studying of motivation by linguocultural units of the thematic group "clothing" in the English and Ukrainian languages" (Mykhalchuk \& Ivashkevych, 2020).

\section{Results}

Результати

The analysis of motivational characteristics in the studied thematic group in the Ukrainian language allowed us to combine linguocultural models of clothes into 11 groups having been formed on the basis of principle of nomination (groups are arranged in descending order of their representativeness in speech): (1) "the form" (18\%); (2) "the purpose of use of the thing (the purpose)" (17\%); (3) "clothing as a material used" (11\%);

(4) "social, national and professional affiliation" (10\%); (5) "the image of the action / the attitude to the action" (9\%); (6) "a way of wearing" (9\%); (7) "the name of parts of a human body" (9\%); (8) "the presence/the absence of any detail" (8\%); (9) "by method of production" (4\%); (10) "a place" (3\%); (11) "main characteristics" $(2 \%)$. 
(1). The principle of nomination "the form". In the Ukrainian language this principle presents the most numerous group, linguocultural models, the formation of which was based on the motivational feature "the form". This group includes: метелик (from "butterfly") - a tie in the form of a bow; банани (from "banana") - a kind of women's pants wide up and narrowed down (shaped like a banana).

(2). The principle of nomination "the purpose of use of the thing (the purpose)". In this group of linguocultural models, in contrast to the group "form", motivation is expressed indirectly and can have the following meanings: "an object for action / performance of a function", "an object for wearing in a certain situation". The group includes the following items of clothing: вітровка (from "а wind") - the same as a storm; гольфи (from the name of the game "golf") - short stockings to the knees on an elastic band (originally intended for golf) or shorts with cuffs that fasten under the knee (originally intended for golf).

(3). The principle of nomination "clothing as a material used". To the group of linguocultural models formed with the use of the motivational feature "material", in the Ukrainian language we have included the following words: ватник (from "cotton wool") quilted cotton jacket or a tank top; шкірянка (from "leather") - a leather jacket or a short leather coat; it is the same as the bat.

(4). The principle of nomination "social, national and professional affiliation". This group is a combination of three subgroups: "social affiliation", "national affiliation" and "professional affiliation". We consider it expedient to unite these subgroups, as they all have one thing in common - "related to the individual characteristics" and they are characterized by emphasized anthropocentrism. To linguocultural models formed on the basis of the motivational feature "nationality", we included the following culturally marked units: угорка (from “Hungarian”) - a hussar jacket; в 'єтнамки (from "Vietnamese") - light (usually rubber) shoes in a form of a sole with a strap between the first and the second toes.

(5). The principle of nomination "the image of the action / the attitude to the action". Prior to the group of linguocultural models, the basis for giving names to those ones is laid down by the motive meaning "the action", include such lexical units of the Ukrainian language: ворim (from "return") - a piece of clothing around the neck; комір (from "the collar") - a piece of clothing, sewn or fastened to the collar, the edges of which "turn" outward; комбінація (from "to combine") - lingerie in a form of a shirt, worn directly under the dress.

(6). The principle of nomination “a way of wearing”. The group of linguocultural models is formed on the basis of the motivational feature "a way of wearing" and it includes the following names of clothes of the Ukrainian language: босоніжки (from "barefoot" + 


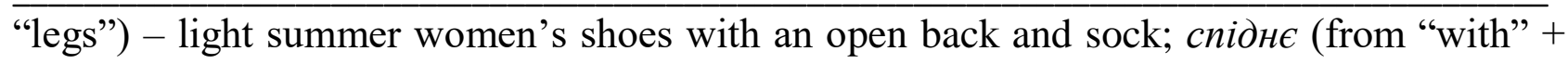
"under" + "bottom") - underwear, underwearing, underclothing.

(7). The principle of nomination “the name of parts of a human body". This group of linguocultural models in the Ukrainian language is not very numerous and is represented by the following lexical units: рукав (from "a hand") - a piece of clothing that covers the hand; рукавиия (from "a hand") - a kind of a glove, with a separation only for the thumb.

(8). The principle of nomination "the presence / the absence of any detail". In the Ukrainian language linguocultural models of this group are formed by adding either the prefix without- or semi-: напівчеревики ("floor" + "shoes") - closed shoes with laces, buttons that reach the ankles (in contemporary colloquial language ankle boots are of a more common option); напівпальто ("floor" + "coat") - a short coat that does not reach the knees.

(9). The principle of nomination "by method of production". In contrast to the English language, where this category is not represented at all, in the Ukrainian language in the studied thematic group we have identified four linguocultural models, formed on the basis of the motivational feature by "method of production": валянки (from "to roll") winter shoes, boots, pile of wool; дублянка (from "to tan") - a coat made of leather, made by the method of tanning.

(10). The principle of nomination "a place". Among the names of clothes in the Ukrainian language, formed on the basis of the motivational characteristics "a place", we have identified the following linguocultural units: панама (from the name of the Panama Peninsula) - annual winged straw or a cloth hat; пісочник (from “a sandbox") - children's summer overalls.

(11). The principle of nomination "main characteristics". This group is also small. It includes three linguocultural units of the studied thematic group: грація (from "grace" grace, beauty in movements) - a kind of a corset, a rigid elastic wide belt covering a torso and supporting a breast; сорочечка (from "to dissolve") - a shirt for babies without buttons, with a cut on the back or the chest.

\section{Conclusions \\ Висновки}

As a result of the research psycholinguistic features of students' understanding of linguocultural units of the thematic group "clothing" in the English and Ukrainian languages were established:

- productivity of students' understanding of linguocultural units of the thematic group "clothing" in the Ukrainian language is determined by the deep meaning of lexical units, semantics and spatio-temporal meanings of linguocultural units, syntactics of lexical 
units, verb and noun basis of clothing nomination, as well as various connections between explicit concepts (metaphorical and metonymic transference), assertive content of the nominative unit denoting "clothing", understanding of inferences, implications, intentions of the expression, explication of visualized (a priori) communicative meanings, etc.;

- the laws of the organization of usual (a priori) and actual (a posteriori) communicative meanings, their interaction, movement, intersection are quite important for understanding by students of linguocultural units of the thematic group "clothing" in the Ukrainian language;

- productivity of students' understanding of linguocultural units of the thematic group "clothing" in the English language is determined by the peculiarity of the presentation of clothing nominations motivated by verbs, adjectives and nouns, understanding the meaning of two noun bases, as well as changing meanings due to emotionally the color of the lexical unit, which depends on a certain principle of nomination ("a form", "a purpose of use of the thing (a purpose)", "social, national and professional affiliation", etc.).

\section{References Лimepamypa}

Alahmadi, A. \& Foltz, A. (2020). Effects of Language Skills and Strategy Use on Vocabulary Learning Through Lexical Translation and Inferencing. Journal of Psycholinguist Research, 49(6), 975-991. https://doi.org/10.1007/s10936-020-09720-9

Drigas, A. \& Karyotaki, M. (2017). Attentional control and other executive functions. International Journal of Emerging Technologies in Learning (iJET), 12(3), 219-233. https://doi.org/10.3991/ijet.v12i03.6587

Mykhalchuk, N. \& Bihunova, S. (2019). The verbalization of the concept of "fear" in English and Ukrainian phraseological units. Cognitive Studies | Études cognitives, Варшава (Польща), 19, 11. https://doi.org/10.11649/cs.2043

Mykhalchuk, N. \& Ivashkevych, E. (2020). Metodyka vyvchennia vmotyvovanosti linhvokulturem tematychnoi hrupy «odezha» $\mathrm{v}$ anhliiskii ta ukrainskii movakh [The methods of studying of motivation by linguocultural units of the thematic group "clothing" in the English and Ukrainian languages]. Rivne: RSUofH. 82 p. [in Ukrainian]. 